\title{
The effect of stocking density on the growth of apple snails native Pomacea bridgesii and exotic Pomacea lineata (Mollusca, Gastropoda)
}

\author{
ESMAR SOUZA JÚNIOR ${ }^{1}$, JOSÉ CARLOS N. DE BARROS ${ }^{1}$, \\ KARLA PARESQUE ${ }^{2}$ and RODRIGO R. DE FREITAS ${ }^{3}$ \\ ${ }^{1}$ Departamento de Pesca e Aquacultura, Universidade Federal Rural de Pernambuco, \\ Rua Dom Manoel de Medeiros, s/n, Bairro de Dois Irmãos, 52171-030 Recife, PE, Brasil \\ ${ }^{2}$ Instituto de Biociências, IB/USP, Universidade de São Paulo, Rua do Matão, trav. 14, nº 321, \\ Cidade Universitária, 05508-090 São Paulo, SP, Brasil \\ ${ }^{3}$ Universidade Federal do Espírito Santo, Centro Universitário Norte do Espírito Santo, \\ Departamento de Engenharias e Computação, Núcleo de Pesquisa em Gestão de Sistemas de Produção (NPGSP), \\ Laboratório de Gestão Costeira - Aquicultura e Pesca (LGCap), \\ Rodovia BR 101 Norte, Km 60, Bairro Litorâneo, 29932-540 São Mateus, ES, Brasil
}

Manuscript received on January 12, 2011; accepted for publication on May 9, 2012

\begin{abstract}
The demand for alternative food sources is currently in evidence in the world and, therefore, the culture of animal species considered not conventional makes this theme relevant and appropriate. In the present study, the species Pomacea lineata and Pomacea bridgesii, each with three stowage densities (0.5 [T1], 1 [T2], and 1.5 [T3] animal/L), were tested. They were analyzed regarding growth rate, weight gain, final biomass, feed conversion and percentage of survival. There was not any statistically significant difference between the different densities for both species. The final average weight in the three waterworks did not differ significantly in P. bridgesii. In P. lineata, T1 $(22.3 \pm 1.80 \mathrm{~g})$ was significantly higher than T2 and T3. On the other hand, the absolute gain of weight in P. lineata and P. bridgesii was significantly higher in T1 $(21.9 \pm 1.80 \mathrm{~g}$ and $37.2 \pm 6.34 \mathrm{~g})$ than in T2 and T3 respectively. In contrast, the gain of biomass of P. lineata and $P$. bridgesii was significantly higher in T3 $(276.3 \pm 33.16 \mathrm{~g}$ and $431.4 \pm 37.20 \mathrm{~g})$ than in T1 and T2, respectively. Based on the results obtained, all species studied presented potential for aquaculture, mainly P. bridgesii, distinguished for showing a better development even in waterworks with higher densities.
\end{abstract}

Key words: mollusk, aquaculture, alternative food source, feed conversion, grow rate, weight gain.

\section{INTRODUCTION}

Currently, world aquaculture has been prominent for the growth and successive rise of productivity. Its share on world fish production attains values over 55.1 million tons/year (FAO 2010), conferring to this type of production a prominent position in the sector of international meat production.

Correspondence to: Esmar Souza Júnior

E-mail: esmar.souza@yahoo.com
Having the fish gathering practically reaching its maximum limit of sustainable exploitation, with a growth rate inferior to $1 \%$ per year, aquaculture has been showing an average growth of $6.6 \%$ per year (FAO 2005).

Towards the continuous rise in population rate and, consequently, food demand, it is noticeable a protein-caloric malnutrition, mainly in underdeveloped countries (Freitas and Barroso 
2006). Mainly with the reduction on the availability of fishing food products, the demand for different food sources has been growing. With that in mind, it has been even more noticeable the exploitation and the culture of animal species considered not conventional and not traditionally commercialized.

Among the animals with high potential as food source there can be found mollusks of the genre Pomacea, which are rich in proteins, carbohydrates, fat, glycogen and essential amino acids. The species Pomacea lineata (Spix
1827), and Pomacea bridgesii (Reeve 1856) are gastropods from the Ampullariidae family and inhabit low marginal zones of rivers, brooks, lakes and calm water swamps (Figure 1). The species $P$. lineata can be widely found in the South American continent, but they are currently spread in the Northeast area of Brazil (Guimarães 1981). The species $P$. bridgesii is native from Florida, USA, and it can be found in lakes and swamps of North America, making of this an exotic species in the South American continent.

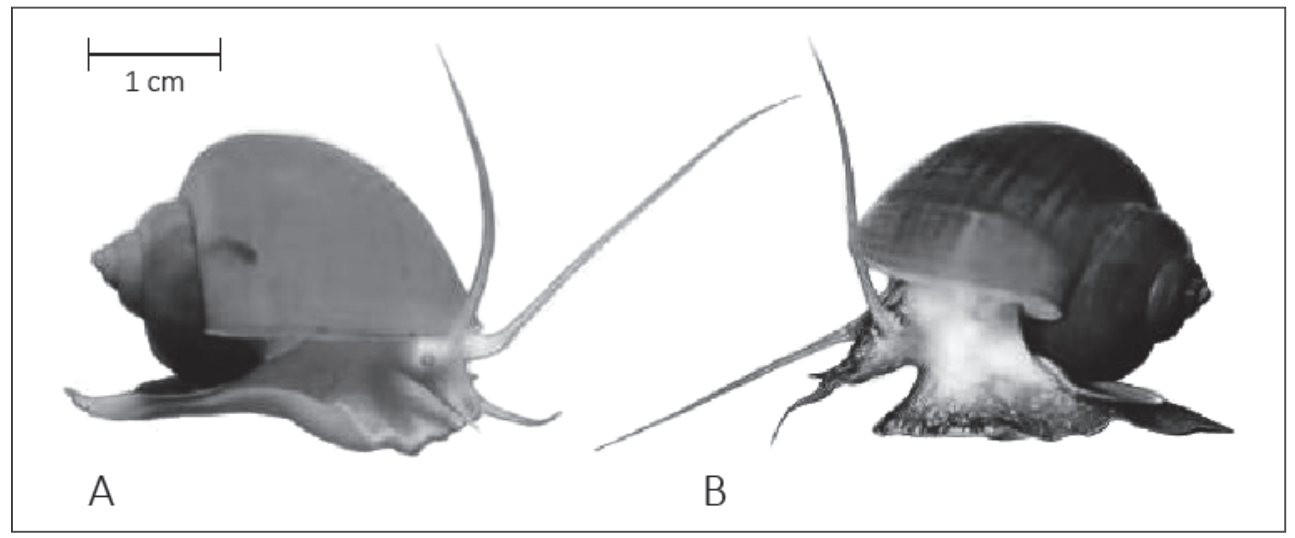

Figure 1 - Side view of: A) Pomacea bridgesii B) Pomacea lineata (Chesquiere, s/d).

Pomaceas are fed of plants and seaweed leftovers, their own aerial and bronchial breathing, and internal fertilization and they are oviparous (Guimarães 1981).

The snails can be used to other finalities. Bombeo-Tuburan et al.(1995) studied the application of the golden apple snail Pomacea monodon, a native snail from South America, how food supply in shrimp culture. They concluded that it increases shrimp procuction and improves the size-frequency distribution of the harvest. Currently, the snails have been used in ecotoxicology bioassays (Das and Khangarot 2010) and are helpful for advancing water quality guidelines for protecting aquatic biota (Das and Khangarot 2011).

In this study, the species were used for presenting high reproduction rates, growth and precocious sexual maturity, as well as for being rustic animals already used as food for the population of Trinidad, The Guianas and North and Northeast of Brazil. The aim of this study was to evaluate the performance of Pomacea lineata and Pomacea bridgesii species cultivated in different stowage densities with the purpose of showing the viability of water production of these species and a possible emerge of a new food source.

\section{MATERIALS AND METHODS}

The experiment was developed in the installations of the Malacology Museum, in the Department of Fishing and Aquaculture, Universidade Federal Rural de Pernambuco, in the city of Recife, PE, Brazil, UFRPE (0803'14 S - 3452'52 W).

The animals were collected in the Fish Culture Koike station (UFRPE - Recife-PE). These samples 
were kept in two masonry tanks of 1,000 liters each, species were separated and it was awaited for 30 days for pomaceas to spawn.

At the moment of spawn, two spawns from P. lineata and P. bridgesii were selected and they were transferred to emergence tanks of $40 \times 40 \mathrm{x}$ $40 \mathrm{~cm}$, filled with $5 \mathrm{~L}$ of water, put under floating screens, and kept there until spawn, which occurred after 15 days approximately. After hatch, more 10L of water were added to these tanks. The recently hatched animals were kept in this tank until they were 30 days old.

The experiment was conducted through an entirely casualized delineation, with a $2 \times 3$ factorial scheme, in which two species of P. bridgesii and $P$. lineata were tested in three different stowage $(0.5 ; 1.0$ and 1.5 animal/L) with three repetitions, amounting to a total of 6 waterworks. In the experiment, 18 tanks tanks were used, disposed in a water recirculation closed system (Figure 2). The tanks had an area of $0.165 \mathrm{~m}^{2}$, a total volume of $15 \mathrm{~L}$, filled with $10 \mathrm{~L}$ of water. Each tank had a place for water provision and another for drainage. The drained water from the tanks descended to the pipes by gravity up to the filter. After passing through the filter, the water was reinserted in the system by a submerse pump $(1,400 \mathrm{~L} / \mathrm{h})$, pumping in a speed of $605 \mathrm{~L} / \mathrm{h}$ and with a renew volume of approximately 18 minutes.

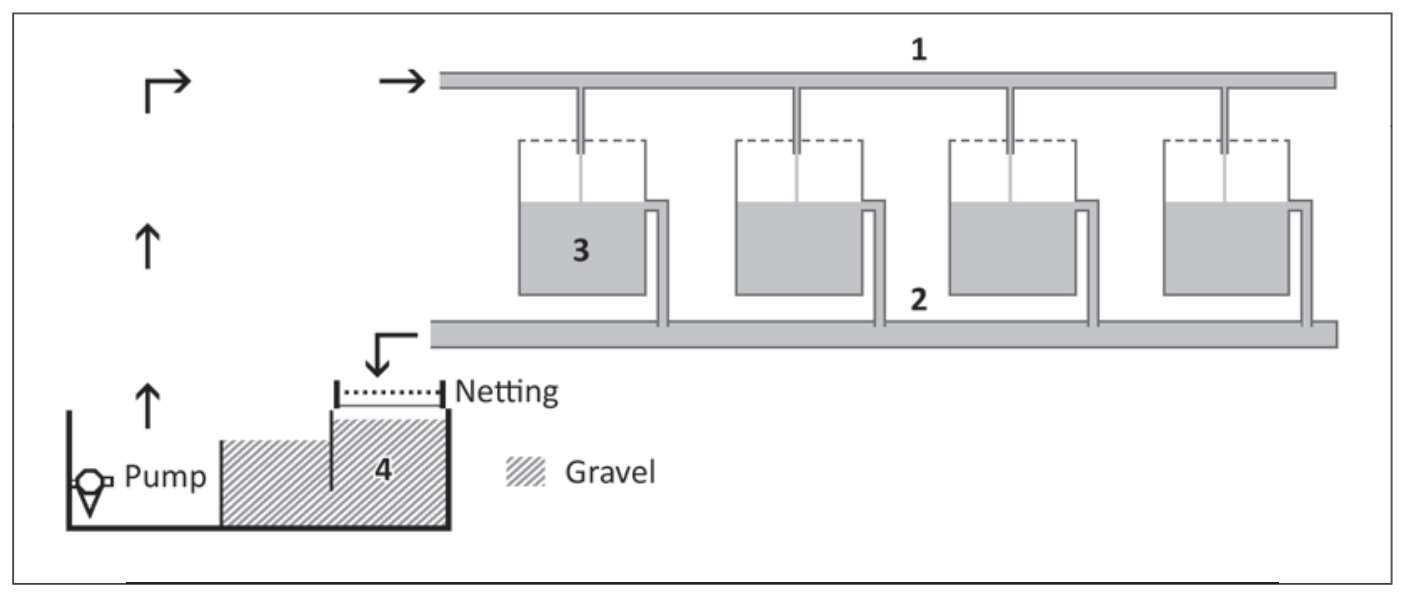

Figure 2 - Scheme of the water recirculation closed system (1: Water Supply Piping Provision - 2: Water Drainage Pipe - 3: Tank - 4: Biological Filter).

The filter used was adapted, according to Valenti (1998), for sweet water prawns larviculture. It was divided in two parts: the first with a mechanical seep and the second part consisted of a biological filter.

The tanks were constantly cleaned by siphons, in order to collect the excess of animal excrement, and the filter was backwashed every 30 days. The animals were daily fed with commercial pellet food for prawns (35\% protein levels). The food was heavy and offered in trays that were collected on the following day by the morning, when leftovers were also collected. The leftovers were put to dry on the greenhouse until acquiring constant weight, only then being weighted. Initially, it was used a food rate of $15 \%$ of biomass and every 15 days this rate was readjusted, considering the consumption and the biometry of the animals.

The following growth variables were calculated, in which: $\mathrm{Fw}=$ Final weight; Iw = Initial weight and $\mathrm{T}=$ time passed in days. Gain of Biomass $(\mathrm{GB}=(\mathrm{Fw} x$ number of animals taken from the tank) - (Iw x number of animals kept) ; Feed Conversion $(\mathrm{FC}=$ Food consumption (dry material) / Gain of Biomass); Specific Growth Rate $(\mathrm{SGR}=(\log \mathrm{FW}-\log \mathrm{Iw}) \times 100 / \mathrm{T})$; 
Absolute Weight Gain (increment of the animal weight during culture. $\mathrm{AWH}=\mathrm{FW}-\mathrm{Iw})$; Relative Weight Gain (expressed in growth percentage during culture. RWG = Fw - Iw x $100 /$ Iw) and finaly Final biomass $(\mathrm{Fb}=\mathrm{FW}$ x number of animals taken from the tank / Total tank volume).

After the culture period, the animals were taken from the tank and slaughtered by thermal shock. In order to profit from their carcasses and to obtain dry weight, the soft parts of the operculum and the shell were removed. After that, the soft parts were weighted in an analytical balance and then subtracted from the total weight, obtained previously in biometry. The soft parts that were weighted were wrapped in aluminum foil. They were then identified and taken to the greenhouse, in a temperature of $70^{\circ} \mathrm{C}$ until obtaining constant weight. After the process of drying, the soft parts were weighted again to obtain of dry weight.

Variables of the culture water system were analyzed weekly, in order to check the efficiency of the biological filter, to check the water quality and to maintain the levels above $100 \mathrm{mg} / \mathrm{L}$, by adding Calcium Magnesium Carbonate (dolomite, $\mathrm{CaMg}\left[\left(\mathrm{CO}_{3}\right)_{2}\right]$. The variables analyzed were: temperature $\left({ }^{\circ} \mathrm{C}\right)$ and dissolved oxygen $(\mathrm{mg} / \mathrm{L})$ measured with a digital oximeter, $\mathrm{pH}$ measured with a digital $\mathrm{pH}$ meter, hardness $\left(\mathrm{mh} / \mathrm{L}\right.$ of $\left.\mathrm{CaCO}_{3}\right)$, alkalinity $\left(\mathrm{mg} / \mathrm{L}\right.$ of $\left.\mathrm{CaCO}_{3}\right)$ and ammonia $(\mu \mathrm{g} / \mathrm{L})$ measured by samples analyzed in the Limnology Laboratory from the Fishing Engineering Department of UFRPE.

The statistical analysis used was from Program SAEG 9.0, through Analysis of Variance, and the comparison of means made through Tukey's test at the $5 \%$ level.

\section{RESULTS AND DISCUSSION}

At the end of 16 weeks of culture, the average weight obtained by $P$. lineata, stocked up with 30 days in a density of 0.5 animal/L, was of $22.3 \mathrm{~g}$, weight superior of that obtained by (Rezende 1998), which was of $3.05 \mathrm{~g}$ for animals isolated reared, and of $1.48 \mathrm{~g}$ for grouped animals in a density of $0.5 \mathrm{animal} / \mathrm{L}$ for 4 months. This difference was probably given by the difference of the culture water average temperature, being $21^{\circ} \mathrm{C}$ against $28^{\circ} \mathrm{C}$ in this experiment. There was not any significantly difference between the gains of biomass reached in the higher density treatment, considering that there was no difference in weight gain.

Considering the development of P. bridgesii, the treatment with higher density differed from the others by a less gain of weight, what may have been caused by social factors. There was not any statistical difference between the treatments considering feed conversion, but when compared between the species, the samples of $P$. bridgesii had a better conversion.

Even though the animals were not fed with a balanced diet for their species, a higher conversion rate in animal protein was noted, which was already reported by Santos (1995), Padilla et al. (2000), Sharfstein and Steinman (2001) and Mendoza et al. (2002).

The average survival rate obtained for the species was $100 \%$ for the animals stocked up in densities of 0.5 animal/L, not showing any significantly difference when compared to the other treatments. Therefore, on treatments with higher density it was noted higher mortality rates, because of male dispute for female and for food. In addition, cannibalism was also directly related to the density of stowage (Rezende 1998) (Table I).

There were not found any defects on shells, certainly due to corrections made with addition of dolomite calcareous to the control of water hardness on the system.

In some $P$. bridgesii samples that were once submitted to higher densities (T-2 and T-3), some wounds were found in the mantles that prevented the shell formation. They were certainly a result of the dispute between the snails, causing a lower performance in these treatments. 
TABLE I

Growth data* of: A) Pomacea lineata and B) P. bridgesii.

\begin{tabular}{|c|c|c|c|c|c|c|}
\hline \multirow[b]{3}{*}{ Growth variable } & \multicolumn{3}{|c|}{ A) } & \multicolumn{3}{|c|}{ B) } \\
\hline & \multicolumn{3}{|c|}{ P. lineata } & \multicolumn{3}{|c|}{ P. bridgesii } \\
\hline & D1 & D2 & D3 & D1 & D2 & D3 \\
\hline Initial Avarage Weight (g) & 0.315 & 0.259 & 0.273 & 0.386 & 0.403 & 0.357 \\
\hline Stowage Density (ind./L) & 0.5 & 1 & 1.5 & 0.5 & 1 & 1.5 \\
\hline Cultivation Time (weeks) & 16 & 16 & 16 & 16 & 16 & 16 \\
\hline Final Average Weight (g) & $22.3 \mathrm{a}$ & $18.0 \mathrm{~b}$ & $19.5 \mathrm{ab}$ & 37.6 & 37.2 & 30.4 \\
\hline Growth Rate (\%/day) & 1.65 & 1.65 & 1.66 & 1.77 & 1.76 & 1.72 \\
\hline Absolute Weight Gain (g) & $21.9 \mathrm{a}$ & $17.8 \mathrm{~b}$ & $19.2 \mathrm{ab}$ & $37.2 \mathrm{a}$ & $36.8 \mathrm{a}$ & $30.1 \mathrm{~b}$ \\
\hline Relative Weight Gain (\%) & 6.984 & 6.920 & 7.062 & 9.725 & 9.267 & 8.434 \\
\hline Survival Rate (\%) & 100 & 100 & 95.6 & 100 & 96.7 & 95.6 \\
\hline Final Biomass $(\mathrm{g} / \mathrm{L})$ & 111.3 & 180.1 & 280.2 & 187.9 & 359.6 & 436.5 \\
\hline Gain of Biomass (g) & $109.7 \mathrm{a}$ & $177.5 \mathrm{~b}$ & $276.3 \mathrm{c}$ & $186.0 \mathrm{a}$ & $355.7 \mathrm{~b}$ & $431.4 \mathrm{c}$ \\
\hline Feed Conversion & 0.84 & 0.86 & 0.84 & 0.70 & 0.71 & 0.76 \\
\hline
\end{tabular}

*To the each species, different letters on the same line imply statistically different averages $<0.05$ (the species aren't being compared). $\mathrm{D} 1=$ density of $0.5 \mathrm{animal} / \mathrm{L}$; D2= density of $1.0 \mathrm{animal} / \mathrm{L}$; D3= density of $1.5 \mathrm{animal} / \mathrm{L}$.

Regarding the water quality, samples of $P$. bridgesii were stocked up in the system approximately two months after the $P$. lineata samples were stocked up, due to problems occurred in the beginning of the initial culture of $P$. bridgesii species. Because of that, it was necessary to expose two phases in the water quality follow up.

Under this experiment the average water temperature was kept in excellent levels for a good development of these species, according to Guimarães (1981) and Estebenet and Cazzaniga (1992). The pH was kept between the considered normal limits (Guimarães 1981), certainly due to the correction of water hardness with the addition of dolomite calcareous.

Regarding the output of carcass and dry weight, mollusks shells, in general, consist basically of calcium carbonate and are plenty used as calcium supplement, just like oyster flour. The average output of the species carcass in the culture was of $50 \%$ in P. lineata and $48.6 \%$ in P. bridgesii. There was not any statistical difference in the carcass output when compared to the results obtained in the treatments.
The percentage of proteins, carbohydrates and other nutrients are considered higher in the dry bases of the animals. The protein proportion, for instance, exceeds from $13.01 \%$ to $44.26 \%$ in the analysis made from Rezende (1992), so it is of great importance the output of the dry bases of these animals. The dry weight of the sift parts represented $13.3 \%$ and $14.4 \%$ for $P$. lineata and $P$. bridgesii respectively. There was not any statistical difference when the three treatments are compared.

When it comes to the weight and length of both species in the three stowage densities, after the analysis of variance, the Tukey's test was made for weight and length variables in the eight periods during the experiment. In Table II, it can be found the result of Turkey's test for weight in the periods analyzed, except for period 4 , which showed interaction between species and density (Table III). It can even be seen that the species P. bridgesii showed values significantly higher than $P$. lineata (Table II). But the best density was of 5 animals/tank. 
TABLE II

Tukey's test for weight variable in different rating periods*.

\begin{tabular}{ccc|ccc}
\hline \multirow{2}{*}{ Period } & \multicolumn{2}{c|}{ Species } & \multicolumn{3}{c}{ Density (animals/tank) } \\
\cline { 2 - 6 } & P. bridgesii & P. lineata & 5 & $0.3117 \mathrm{~b}$ & $0.3148 \mathrm{~b}$ \\
\hline 1 & $0.3692 \mathrm{a}$ & $0.2823 \mathrm{~b}$ & $0.3508 \mathrm{a}$ & $1.9443 \mathrm{a}$ & $1.8852 \mathrm{a}$ \\
2 & $2.6138 \mathrm{a}$ & $1.2910 \mathrm{~b}$ & $2.0277 \mathrm{a}$ & $5.5673 \mathrm{ab}$ & $5.0912 \mathrm{~b}$ \\
3 & $8.3325 \mathrm{a}$ & $2.5000 \mathrm{~b}$ & $5.7403 \mathrm{a}$ & $14.3182 \mathrm{ab}$ & $13.1458 \mathrm{~b}$ \\
5 & $20.3872 \mathrm{a}$ & $8.3746 \mathrm{~b}$ & $15.5787 \mathrm{a}$ & $19.9980 \mathrm{ab}$ & $17.8728 \mathrm{~b}$ \\
7 & $26.3786 \mathrm{a}$ & $13.7053 \mathrm{~b}$ & $22.2550 \mathrm{a}$ & $23.8203 \mathrm{ab}$ & $21.2470 \mathrm{~b}$ \\
8 & $31.3157 \mathrm{a}$ & $16.1823 \mathrm{~b}$ & $26.1797 \mathrm{a}$ & $26.4185 \mathrm{ab}$ & $23.8835 \mathrm{~b}$ \\
\hline
\end{tabular}

*Means followed by different lowercase letters on the same line are different, by the Tukey test at the $5 \%$ level.

To period 4 (Table III), it can be seen that $P$. bridgesii showed higher weight in densities of 5 and 10 animals/tank, while $P$. lineata did not show any significant change to stowage density. This interaction showed in period 4 for the weight, can be explained through intrinsic biological relations of the species in the experiment.

\section{TABLE III}

Unrolling of interaction between species and density for the variable weight in period $4 *$, through Tukey's test.

\begin{tabular}{cccc}
\hline \multirow{2}{*}{ Species } & 5 & 10 & 15 \\
\cline { 2 - 4 } & 5 & \multicolumn{3}{c}{ Density } \\
\hline P. bridgesii & 15.0153 a A & 14.0133 a A & 12.3727 b A \\
P. lineata & 3.9500 a B & 3.8167 a B & 3.6980 a B \\
\hline
\end{tabular}

* Means followed by different lowercase letters on the same line are different, by the Tukey test at the $5 \%$ level.
Table IV presents the result of the test of length average in the eight periods rated, except for periods 4 and 8 (Table $\mathrm{V}$ ) that showed a significant interaction between species and density. The behavior was equal to the weight, in which the species $P$. bridgesii and the density of 5 animals/ tank were superior.

It can be seen in Table $\mathrm{V}$ that in both periods P. bridgesii was superior to the two initial stowage densities (5 and 10 animals/tank) and that this species was superior than $P$. lineata in all stowage densities. The species $P$. lineata did not show any difference in any of the stowage densities. The interaction factor in periods 4 and 8 for the weight is explained in the same way mentioned above in relation to growth.

TABLE IV

Tukey's test for growth variable in different rating time.*

\begin{tabular}{ccc|ccc}
\hline \multirow{2}{*}{ Period } & \multicolumn{2}{c|}{ Species } & \multicolumn{3}{c}{ Density (animals/tank) } \\
\cline { 2 - 6 } & P. brigdesi & P. lineata & 5 & 10 & $1.1352 \mathrm{a}$ \\
\hline 1 & $1.2388 \mathrm{a}$ & $1.0637 \mathrm{~b}$ & $1.1468 \mathrm{a}$ & $1.1717 \mathrm{a}$ & $2.0498 \mathrm{a}$ \\
2 & $2.3983 \mathrm{a}$ & $1.7491 \mathrm{~b}$ & $2.0980 \mathrm{a}$ & $2.0736 \mathrm{a}$ & $2.8545 \mathrm{a}$ \\
3 & $3.6204 \mathrm{a}$ & $2.2214 \mathrm{~b}$ & $2.9837 \mathrm{a}$ & $2.9247 \mathrm{a}$ & $3.8457 \mathrm{~b}$ \\
5 & $4.6814 \mathrm{a}$ & $3.2953 \mathrm{~b}$ & $4.1243 \mathrm{a}$ & $.9952 \mathrm{ab}$ & $4.9143 \mathrm{a}$ \\
7 & $5.5309 \mathrm{a}$ & $3.7607 \mathrm{~b}$ & $4.5665 \mathrm{a}$ & $4.4565 \mathrm{a}$ & $4.4602 \mathrm{~b}$ \\
\hline
\end{tabular}

*Means followed by different lowercase letters on the same line are different, by the Tukey test at the $5 \%$ level. 
TABLE V

Unrolling of interaction between species and density and for the variable weight in periods 4 and $8 *$ through Tukey's test.

\begin{tabular}{clccc}
\hline \multirow{2}{*}{ Time } & Species & \multicolumn{4}{c}{ Density } \\
\cline { 3 - 5 } & & 5 & 10 & 15 \\
\hline \multirow{2}{*}{4} & P. bridgesii & 4.5213 a A & $4.2590 \mathrm{ab} \mathrm{A}$ & $3.9537 \mathrm{~b} \mathrm{~A}$ \\
& P. lineata & $2.5687 \mathrm{a}$ B & $2.4140 \mathrm{a} \mathrm{B}$ & $2.5420 \mathrm{a} \mathrm{B}$ \\
\multirow{2}{*}{8} & P. bridgesii & $5.3290 \mathrm{ab} A$ & $5.5887 \mathrm{a} \mathrm{A}$ & $5.1943 \mathrm{~b} \mathrm{~A}$ \\
& P. lineata & $4.3587 \mathrm{a} \mathrm{B}$ & $4.0210 \mathrm{a} \mathrm{B}$ & $4.0957 \mathrm{a} \mathrm{B}$ \\
\hline
\end{tabular}

*Means followed by different lowercase letters on the same line are different, by the Tukey test at the $5 \%$ level.

\section{FINAL CONSIDERATIONS}

In culture conditions of laboratory, samples of native P. bridgesii showed growth and gain of weight superior than exotic $P$. lineata. Regarding the density of species, $P$. bridgesii showed to be more sensitive to density, whereas $P$. lineata's density is directly linked to the good water conditions of the culture.

Both species showed a high output of carcass and a moderate output of dry weight.

The species studied can present potential for being cultured in large scale as possible alternative food source and other applications, but it is necessary additional studies in the interdisciplinary areas to check the viability. The test of different kinds of food would clarify the best way of production, cheapen the productive process and become possible the culture in small farms. The test of culture in a bigger scale also is necessary to investigate the potentiality of these productions.

\section{RESUMO}

A demanda por fontes alternativas de alimento está em evidência atualmente no mundo e assim, o cultivo de espécies de animais considerados não convencionais, torna o tema relevante e apropriado. No presente estudo, cada espécies Pomacea lineata e Pomacea bridgesii, foram testadas com três densidades de estocagem $(0,5$ [T1], 1 [T2], and 1,5 [T3] animal/L). Avaliou-se, taxa de crescimento, ganho do peso, biomassa final, conversão alimentar e porcentagem de sobrevivência, não havendo nenhuma diferença estatisticamente significativa entre as diferentes densidades para ambas as espécies. $O$ peso final médio nos três tratamentos não diferiu significativamente para a $P$. bridgesii. Para $P$. lineata, o T1 $(22,3 \pm 1,80 \mathrm{~g})$ foi significativamente mais elevado do que o T2 e T3. Por outro lado, o ganho absoluto do peso na $P$. lineata e $P$. bridgesii foi significativamente mais elevado em T1 $(21,9 \pm 1,80 \mathrm{~g}$ e $37,2 \pm 6,34 \mathrm{~g})$ do que no T2 e T3, respectivamente. Em contraste, o ganho de biomassa da P. lineata e P. bridgesii foi significativamente mais elevado no tratamento T3 $(276,3 \pm 33,16$ g e $431,4 \pm 37,20 \mathrm{~g})$ do que o $\mathrm{T} 1$ e o $\mathrm{T} 2$, respectivamente. Baseado nos resultados obtidos, todas as espécies estudadas apresentaram potencial para aquicultura, principalmente a $P$. bridgesii que se destacou por mostrar um desenvolvimento melhor, mesmo nos tratamentos com densidades mais elevadas.

Palavras-chave: molusco, aquicultura, fonte alternativa de alimento, conversão alimentar, taxa de crescimento, ganho de peso.

\section{REFERENCES}

BOMBEO-TUBURAN I, FUKUMOTO S AND RodRIGUEZ EM. 1995. Use of the golden apple snail, cassava, and maize as feeds for the tiger shrimp, Penaeus monodon, in ponds. Aquaculture 131: 91-100.

DAS S AND KHANGAROT BS. 2010. Effects of copper on the egg development and hatching of a freshwater pulmonate snail Lymnaea luteola L. J Hazard Mater 179: 665-675.

DAS S AND KHANGAROT BS. 2011. Bioaccumulation of copper and toxic effects on feeding, growth, fecundity and development of pond snail Lymnaea luteola L. J Hazard Mater 185: 295-305.

Estebenet AL AND CAZZAniga NJ. 1992. Growth and demography of Pomacea canaliculata (Gastropoda: Ampullariidae) under laboratory conditions. Malacol Rev 25: $1-12$.

FAO. 2005. Fisheries and Aquaculture Department. Fisheries Department, Fishery Information, Data and Statistics Unit. Fishstst Plus: Universal Software for Fishery Statistical Time Series. Version 2.3.

FAO. 2010. Food and Agriculture Organization of the United Nations. The state of world fisheries and aquaculture. Rome, Italy, FAO Fisheries and Aquaculture Department, 180 p. ISBN 978-92-5-106675-1. 
Freitas RR AND BARRoso GF. 2006. Conflitos de uso dos recursos costeiros: desafios para sustentabilidade do cultivo de moluscos. Caderno Virtual de Turismo (UFRJ) 6(2): 43-50.

GUIMARÃES CT. 1981. Algumas observações de campo sobre biologia e ecologia de Pomacea haustrum (Reeve 1856) (Mollusca, Pilidae). Mem I Oswaldo Cruz 4(76): 343-351.

Mendoza RC, Aguilera M, Hernández J, Montemayor AND CRUZ E. 2002. Elaboración de dietas artificiales para el cultivo del caracol manzana (Pomacea bridgesii). Revista Electrónica Aquatic 16: 1-17.

PAdilla P ET AL. 2000. Cultivo y Procesamiento del churo. Instituto de Investigaciones de la Amazonía Peruana -IIAP - Iquitos - Perú, 49 p.

REZENDE C. 1992. Características nutricionais e sensoriais do Aruá (Pomacea lineata) (Spix 1827). Dissertação (Mestrado em Ciências Biológicas). Lavras (MG): Universidade Federal de Lavras. (Unpublished).
Rezzende GJR. 1998. Pomacea lineata (Spix 1827) (Mollusca, Gastropoda, Ampullariidae): efeito do agrupamento sobre o peso. Dissertação (Mestrado em Comportamento e Ecologia Animal). Juiz de Fora (MG): Universidade Federal de Juiz de Fora. (Unpublished).

SAntos NN. 1995. Cultivo de Pomacea sordida (Swainson 1823) em cativeiro. Rev Bras Ciênc Vet 3(2): 81-86.

SHARFSTEIN B AND STEINMAN AD. 2001. Growth and survival of the Florida apple snail (Pomacea paludosa) fed 3 naturally occurring macrophyte assemblages. J N Am Benthol Soc 1(20): 84-95.

VALENTI CV. 1998. Carcinicultura de água doce: Tecnologia para a produção de camarões. Brasília: IBAMA, 383 p. 